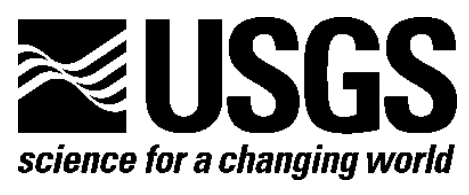

\title{
Using Information From Global Climate Models to Inform Policymaking-The Role of the U.S. Geological Survey
}

By Adam Terando, David Reidmiller, Steven W. Hostetler, Jeremy S. Littell, T. Douglas Beard, Jr., Sarah R. Weiskopf, Jayne Belnap, Geoffrey S. Plumlee

Open-File Report 2020-1058

U.S. Department of the Interior U.S. Geological Survey 


\section{U.S. Department of the Interior \\ DAVID BERNHARDT, Secretary}

\section{U.S. Geological Survey James F. Reilly II, Director}

U.S. Geological Survey, Reston, Virginia: 2020

For more information on the USGS-the Federal source for science about the Earth, its natural and living resources, natural hazards, and the environment-visit https://www.usgs.gov/ or call 1-888-ASK-USGS (1-888-275-8747).

For an overview of USGS information products, including maps, imagery, and publications, visit https://store.usgs.gov/.

Any use of trade, firm, or product names is for descriptive purposes only and does not imply endorsement by the U.S. Government.

Although this information product, for the most part, is in the public domain, it also may contain copyrighted materials as noted in the text. Permission to reproduce copyrighted items must be secured from the copyright owner.

Suggested citation:

Terando, A., Reidmiller, D., Hostetler, S.W., Littell, J.S., Beard, T.D., Jr., Weiskopf, S.R., Belnap, J., and Plumlee, G.S., 2020, Using information from global climate models to inform policymaking-The role of the U.S. Geological Survey: U.S. Geological Survey Open-File Report 2020-1058, 25 p., https://doi.org/10.3133/ofr20201058. 


\section{Acknowledgments}

The authors gratefully acknowledge scientific peer reviews by USGS reviewers (Dr. Julio Betancourt, Dr. Dan Muhs, and Dr. Deborah Willard), scientific peer reviews by external reviewers (Dr. David Raff, U.S. Department of the Interior, Bureau of Reclamation; and Dr. Gavin Schmidt, NASA), and edits by USGS technical editor Jan Ishee. All were instrumental in improving this report. 


\section{Contents}

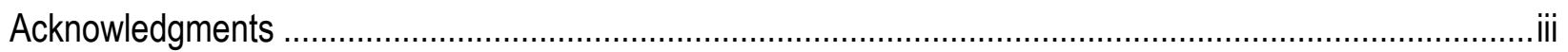

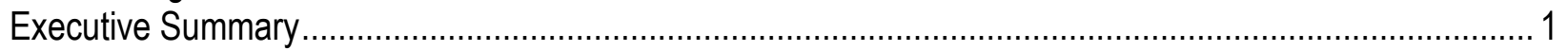

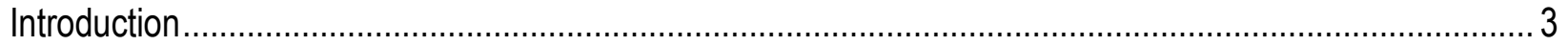

Climate Change as a Risk Management Challenge ………............................................................. 4

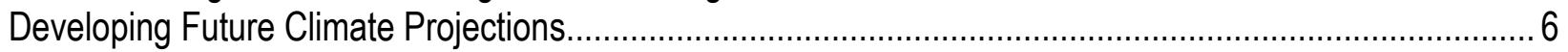

Global Climate Models .........................................................................................................

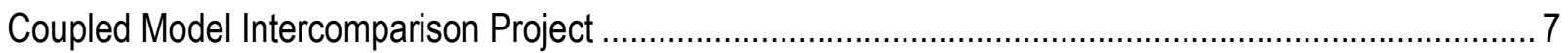

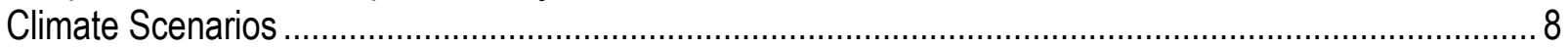

International Research Collaboration in the Development of Climate Scenarios ................................. 8

Range of Air Temperature Response for the Conterminous United States..................................... 12

Uncertainty in Climate Projections and Model Accuracy .................................................................. 14

Representative Concentration Pathways in a Policymaking Context ................................................. 17

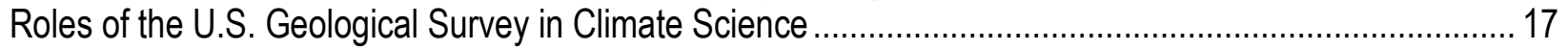

Federal Government's Need for Climate Science and Climate Impact Science ........................................ 18

How U.S. Geological Survey Climate Science Is Provided to the Department of the Interior to Inform

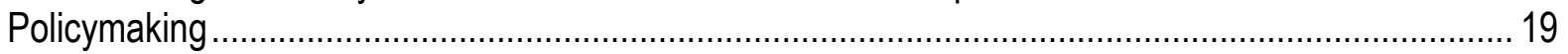

Ongoing Efforts by the U.S. Geological Survey to Improve Understanding and Communication of

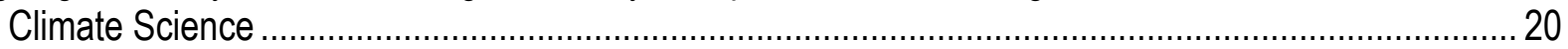

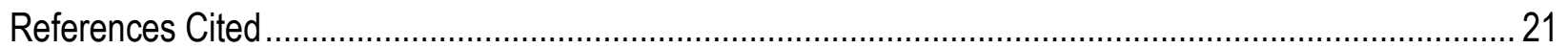

\section{Figures}

1. Graphs comparing modeled changes and three independent estimates of observed changes in the global annual-mean air temperature since 1880 .

2. Diagram showing the decades of the past 120 years when various processes and components of the climate system became regularly included in models.

3. Graphs showing scenario trajectories of global annual carbon emissions, carbon dioxide concentration in the atmosphere, and projected surface air temperature change relative to the annual average for the period from 1950 through 1999.

4. Graphs showing projected changes in mean-annual air temperature relative to the base period of 1950 through 1999 under the four representative concentration pathways (RCPs) for the conterminous United States and the standard error of the mean for the individual model runs for each RCP.

5. Graph showing the fraction of total variance in decadal mean surface air temperature predictions explained by the three components of total uncertainty for the conterminous United States. 


\section{Abbreviations}

$\begin{array}{ll}\text { BLM } & \text { Bureau of Land Management } \\ \mathrm{CH}_{4} & \text { methane } \\ \text { CMIP } & \text { Coupled Model Intercomparison Project } \\ \text { CMIP5 } & \text { Coupled Model Intercomparison Project Phase 5 } \\ \text { CMIP6 } & \text { Coupled Model Intercomparison Project Phase 6 } \\ \text { CO } 2 & \text { carbon dioxide } \\ \text { DOE } & \text { U.S. Department of Energy } \\ \text { DOI } & \text { U.S. Department of the Interior } \\ \text { ECP } & \text { extended concentration pathway } \\ \text { ESM } & \text { Earth system model } \\ \text { GCM } & \text { global climate model } \\ \text { GHG } & \text { greenhouse gas } \\ \text { GtC/yr } & \text { gigatons of carbon per year } \\ \text { IPCC } & \text { Intergovernmental Panel on Climate Change } \\ \text { NASA } & \text { National Aeronautics and Space Administration } \\ \text { NCA } & \text { national climate assessment } \\ \text { NOAA } & \text { National Oceanic and Atmospheric Administration } \\ \text { PCMDI } & \text { Program for Climate Model Diagnosis and Intercomparison } \\ \text { PMIP } & \text { Paleoclimate Modelling Intercomparison Project } \\ \text { RCP } & \text { representative concentration pathway } \\ \text { RCP2.6 } & \text { Representative Concentration Pathway 2.6 (also, RCP4.5, RCP6.0, and RCP8.5) } \\ \text { SRES } & \text { special report on emissions scenarios } \\ \text { SSP } & \text { shared socioeconomic pathway } \\ \text { UCAR } & \text { University Corporation for Atmospheric Research } \\ \text { USGCRP } & \text { U.S. Global Change Research Program } \\ \text { USGS } & \text { U.S. Geological Survey } \\ & \end{array}$





\section{Using Information From Global Climate Models to Inform Policymaking-The Role of the U.S. Geological Survey}

By Adam Terando, David Reidmiller, Steven W. Hostetler, Jeremy S. Littell, T. Douglas Beard, Jr., Sarah R. Weiskopf, Jayne Belnap, Geoffrey S. Plumlee

\section{Executive Summary}

The U.S. Department of the Interior (DOI) and other government agencies (Federal, State, local, and tribal) often must factor the potential impacts of climate change on natural resources, natural systems, infrastructure, and society into their policymaking decisions. Understanding these changes requires the use of models that can simulate the primary physical processes governing the Earth's climate system.

A core capability of the U.S. Geological Survey (USGS) is to provide objective scientific information about the effects of past, present, and potential future climate change to decision makers within and outside the DOI. This report provides an overview of model-based climate science in a risk management context and summarizes how this science within the USGS will continue to follow best scientific practices and when and how the results of this research will be delivered to the DOI and other stakeholders to inform policymaking.

The key takeaways are as follows:

- To fulfill their missions, natural resource managers consider the risks associated with climate change. Climate change is a risk management challenge for society because of the uncertain consequences of that change for natural and human systems across decades to centuries.

- Climate-related science activities within the USGS emphasize research on adaptation to climate change. This research helps inform adaptive management processes and planning activities within other DOI bureaus and by DOI stakeholders.

- Global climate models are increasingly sophisticated numerical representations of the Earth's climate system. These models are able to simulate or replicate many important aspects of Earth's climate, including observed changes in global mean air temperature and ocean heat content attributed to rising atmospheric greenhouse gas concentrations.

- Research groups from institutions around the world regularly participate in a coordinated effort to produce a suite of climate models. The resulting outputs from the various climate models are compared to each other and to observations. This global effort provides a test bed to assess model performance, structural uncertainty, and projections of future change under various prescribed climate scenarios. 
- A climate scenario describes a plausible future outcome associated with a specific set of societal actions that captures the relationships between human choices, greenhouse gas and particulate matter emissions, greenhouse gas concentrations in the atmosphere, and consequent climate change as simulated by global climate models. Because scenarios are developed in a risk-based framework with a high degree of uncertainty about future societal developments, the primary scenarios used in policymaking contexts are usually not assigned a formal likelihood of occurrence (that is, each scenario is considered to be a "plausible" outcome without assuming the "likelihood" of the outcome).

- Examining a range of projected climate outcomes based on multiple scenarios is a recommended best practice because it allows decision makers to better consider both short- and long-term risks and opportunities, while reducing the risk of 'surprises'; that is, negative outcomes that were never considered in the planning process.

- In the near term (years to one to two decades in the future), natural climate variability is the largest source of uncertainty in climate projections. For time periods approximately 30 to 50 years out, scientific uncertainty about the climate system is the largest source of uncertainty in climate projections. Beyond 50 years, human decisions that affect global greenhouse gas emissions are the largest source of uncertainty.

- As part of its routine science practices, the USGS regularly reviews the state of knowledge of climate science, develops and maintains best practices in using global climate models to project climate change impacts, and provides data and interpretations of potential impacts from USGS data sources to the DOI and other stakeholders at the temporal and spatial scales that are the most relevant for planning and policymaking.

- The USGS will report at least once every 5 years (or sooner, as needed) to the DOI on significant new findings in climate science and advances in best practices for incorporating climate information into planning and policymaking activities.

- Examples of best practices that the USGS will continue to follow include:

- Model potential future impacts across a range of climate scenarios whenever feasible, such as across the entire range of greenhouse gas emission scenarios developed by the international scientific community;

- When possible, use multiple climate models (also known as a "multimodel ensemble") to project future impacts resulting from specific scenarios.

- Model potential future impacts over timescales ranging from the near term out to a century or longer, depending on the management decision under consideration.

- Articulate clearly the uncertainties associated with any analysis, including how the uncertainties evolve over the modeled time period and the implications of these uncertainties for interpreting the results.

- Ensure that both climate-related observations and projections continue to receive rigorous peer review.

- As appropriate, revise future-looking impact analyses to incorporate new knowledge and best practices. 
- Specific management and policy decisions within the DOI will reflect different tolerances for risk (for example, a decision affecting a critically endangered species versus one affecting a wildlife refuge boardwalk in a tidal zone), which has implications for what type of information should be considered and how that information should be used. It is suggested that a followup document be produced that would describe in more detail how these management decisions with differing risk tolerances can be made effectively and consistently in light of an uncertain future.

\section{Introduction}

The Department of the Interior (DOI), other U.S. Government agencies, and State, local and tribal governments often must consider the potential future effects of climate change on natural systems, natural resources, infrastructure, and society in their decision making. These changes are of interest because of the potential for negative (or positive) consequences that could affect the ability of these government organizations to accomplish their missions. To assess the likelihood of these future changes, scientists (including DOI and U.S. Geological Survey [USGS] scientists) rely in part on global climate models (GCMs) that simulate the primary physical processes governing the Earth's climate system.

The development and ongoing improvement of climate models, however, still poses significant scientific challenges, and simulations of future climate change are subject to several distinct types of uncertainties (Hawkins and Sutton, 2009, 2012; Hawkins and others, 2016). Significant advances have been made during the past several decades that help reduce these uncertainties, including advances in (1) our understanding of the physical, chemical, and biological processes that define and drive the Earth's climate system; (2) the ability to incorporate these processes in climate models; and (3) increased computational power that enables the development of ever more sophisticated models to simulate the climate system and how it responds to natural and anthropogenic perturbations. Rigorous analysis of the results from successive generations of climate models has progressively increased confidence in the ability of these models to simulate both known past and current changes in the climate and to project how the climate and other Earth system processes are likely to respond to a given scenario of future greenhouse gas (GHG) emissions (Flato and others, 2013). When applied appropriately, climate models provide useful and reliable input for policymaking.

A core capability of the USGS is to provide unbiased scientific information about the effects of past, present, and potential future climate changes to managers within and outside the DOI. The USGS has no policy-setting or regulatory mission; instead, it serves in a science advisory role for DOI and the Federal Government. Making climate information usable is often a complex task because each natural resource management decision requires case-specific, and frequently site-specific, information. The set of insights and best practices used by USGS scientists to address the complexity and uncertainties associated with climate change continues to improve, however, along with usefulness of the science for natural resource management.

This report discusses-

- How climate change is a risk management challenge;

- What climate models are, how climate scenarios are developed and used, and the uncertainties associated with climate scenarios and climate model output;

- Best practices for using climate model output in the policymaking process; 
- The roles of the USGS in climate science;

- The stated needs of the DOI and other stakeholders with respect to USGS climate impact science, including the geographic and temporal scales over which projections are desired to inform policy;

- How USGS climate science is provided to the DOI and other stakeholders for policymaking purposes; and

- How the USGS updates its climate science in response to advances in understanding of the Earth's climate system.

\section{Climate Change as a Risk Management Challenge}

To fulfill their missions successfully, natural resource managers often must consider future risks, including those stemming from climate change. Multiple and independent lines of evidence clearly show that the world has warmed during the past 150 years, especially during the past six decades, and that this warming is primarily attributable to human activities that emit GHGs into the atmosphere (fig. 1). The observed warming, in turn, has triggered and continues to trigger many changes in the planet's physical and biological systems. Detailed descriptions and documentation of observed changes and attribution to human activities are provided by a number of highly vetted and peer-reviewed efforts, such as-

- "State of the climate in 2018," (a special supplement to the Bulletin of the American Meteorological Society; Blunden and Arndt, 2019);

- "Climate science special report-Fourth national climate assessment, volume I" (Wuebbles and others, 2017); and

- "Climate change 2013-The physical science basis. Contribution of Working Group I to the Fifth Assessment Report of the Intergovernmental Panel on Climate Change" (Stocker and others, 2013).

Risks can be explained in a qualitative sense as threats to life, health, and safety; the environment; economic well-being; and other things of value to society. In some cases, risks are described in quantitative terms, such as estimates of how likely a given threat is to occur (probability) and the damages that would result if it did happen (consequences). Climate change is a risk management challenge for society because it presents uncertain consequences for natural and human systems across generations (that is, many decades to centuries; National Research Council, 2010). Climate change results from many complex interactions, and the magnitude and rate of change are associated with uncertainties in future conditions or societal decisions that can serve as risk multipliers, create new risks, or alter existing risks (Clarke and others, 2018).

A significant challenge in managing the risks associated with climate change is the large uncertainty associated with how future atmospheric GHG concentrations will evolve over decadal to century timescales in response to emissions resulting from human activity, mitigation actions, technological and socioeconomic developments, or feedbacks from natural carbon cycling processes. Measuring risk encompasses an assessment of the likelihood and consequences of specific management outcomes and involves judgments about what is of value, what is the ranking of priorities, and what are the tradeoffs associated with different actions and strategies. 


\section{Global Mean Temperature Change}
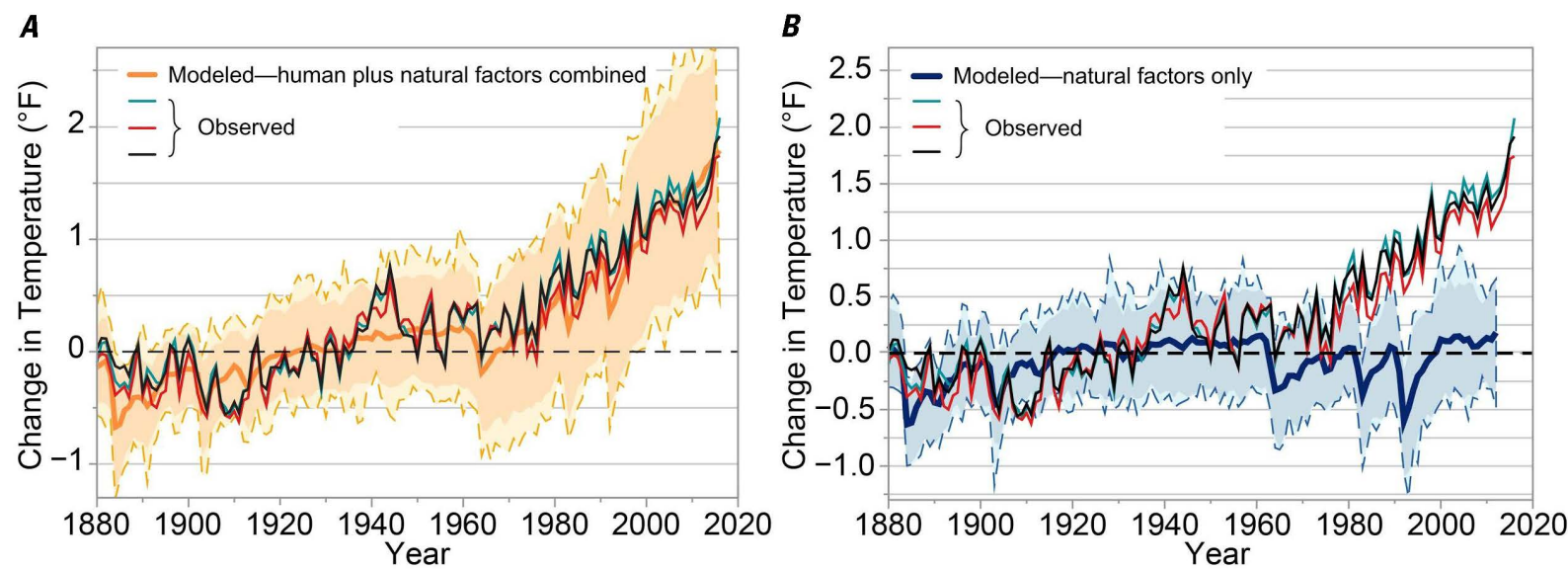

Figure 1. Graphs comparing modeled changes (orange line in panel $A$ and blue line in panel $B$ ) and three independent estimates of observed changes (teal, red, and black lines in both panels) in the global annual-mean air temperature since 1880 . All the time series are presented relative to the average temperature (in degrees Fahrenheit, ${ }^{\circ} \mathrm{F}$ ) over the period from 1901 through 1960. The temperature changes in panel $A$ are from models that include both anthropogenic climate drivers (for example, greenhouse gases [GHGs], ground level ozone, land use change) and natural climate drivers (for example, solar output, orbital variability, observed volcanic eruptions). In contrast, modeled temperatures in panel $B$ include only the natural climate drivers. The thick orange and yellow curve (panel $A$ ) and thick blue curve (panel $B$ ) each represent the mean across dozens of climate model simulations obtained from the Coupled Model Intercomparison Project Phase 5 (CMIP5; Lawrence Livermore National Laboratory, 2008). The shading indicates the standard deviation of all simulations. The outer dashed lines depict the absolute range of temperature differences across all simulations. Panel $B$ shows that after about 1970, the observed global temperatures (green, orange, and black lines) diverge from the temperature simulated by the climate models that consider only natural factors (blue line). The consistency between the trajectory shape and magnitude of the modeled temperature changes and those of the observed temperature changes in panel $A$ show that the observed warming since 1970 is attributable primarily to anthropogenic factors. This modeled response of temperature to GHGs was produced by the earliest versions of climate models that were applied in the 1970s and continues to be produced as the models have undergone significant refinements over the years through addition of many more natural and anthropogenic drivers (Hausfather, Drake, and others, 2020). Figures modified from figure 3.1 of Wuebbles and others (2017); used with permission.

USGS and other DOI scientists help managers assess risks associated with observed and projected changes in climate so that adaptation and mitigation activities can be evaluated and implemented. Adaptation and mitigation activities can be considered complementary strategiesadaptation can minimize the consequences of changes that are already happening, whereas mitigation efforts can reduce future risks (Martinich and others, 2018). Adaptation entails proactive decision making, planning, and investments by individuals, businesses, and governments to counter specific risks from climate change that vary from place to place. USGS science activities emphasize research on adaptation to climate change. The USGS works directly with other DOI bureaus to incorporate new knowledge into adaptive management processes and planning. Climate risk management includes many approaches familiar to natural resource professionals, such as protection and restoration of habitat and development of water 
management procedures and protocols for floods and droughts. Although the DOI is not the primary Federal agency engaged in mitigation activities, the USGS is often involved in developing and evaluating the efficacy of proposed mitigation actions. For example, the USGS was tasked by the Energy Independence and Security Act of 2007 with developing estimates of the geological and biological carbon sequestration potential for the United States; resulting publications included, for example, Zhu and Reed (2014) and U.S. Geological Survey Carbon Dioxide Storage Resources Assessment Team (2013).

\section{Developing Future Climate Projections}

Climate information over a range of timescales is useful for many different applications across the U.S. Government. In some cases, Government agencies are legally required to look forward multiple decades to centuries. For example, the Global Change Research Act of 1990 (Public Law 101-606, which is the legislation that established the U.S. Global Change Research Program [USGCRP]) requires periodic completion of a national climate assessment (NCA) that, among other things, must project major climate-related trends for 25 to 100 years.

Physically based climate projections must use models to quantify and assess responses of the Earth system to an assumed set of future conditions - that is, a scenario. Significant time and effort have been devoted to developing the process that is now used to deliver climate model output to researchers and policymakers for use in decision making. This high level of effort reflects the scientific community's awareness of the complexity of the Earth's climate system, the complexity of societal actions that are now affecting the Earth's climate system, and the stakes involved in decisions affecting both.

\section{Global Climate Models}

Global climate models (GCMs), originally referred to as general circulation models, are numerical representations of the Earth's climate system based on knowledge of how the fundamental laws of physics govern this system. The models originated from numerical weather prediction models used for day-to-day weather forecasts and related activities (such as hurricane tracking and prediction). GCMs account for the conservation of energy, mass, and momentum and how these are exchanged among different components of the climate system. Using these fundamental relationships, GCMs are able to simulate or replicate many important aspects of Earth's climate, such as large-scale patterns of atmospheric circulation, temperature, and precipitation; and observed changes in global mean air temperature and ocean heat content that result from atmospheric GHG concentrations (Flato and others, 2013; Hayhoe and others, 2017).

The complexity of climate models has increased over time as successive models have had additional components of Earth's climate system incorporated into them (fig. 2). For example, as noted above, GCMs were originally referred to as general circulation models when they included only the physics needed to simulate the circulation of the atmosphere or ocean. Today, GCMs simulate many more aspects of the climate system, including atmospheric chemistry and aerosols, land surface interactions, land and sea ice, and, increasingly, interactive biogeochemical cycles. Models that include this last component are also referred to as Earth system models (ESMs; Hayhoe and others, 2017). For specific applications, nested models (that is, the application of a mesoscale regional climate model that is driven by the coarser scale GCM output) that translate or "downscale" these processes to the region of interest are often used (for example, Hostetler and others, 2018). 
A Climate Modeling Timeline

(When Various Components Became Commonly Used)
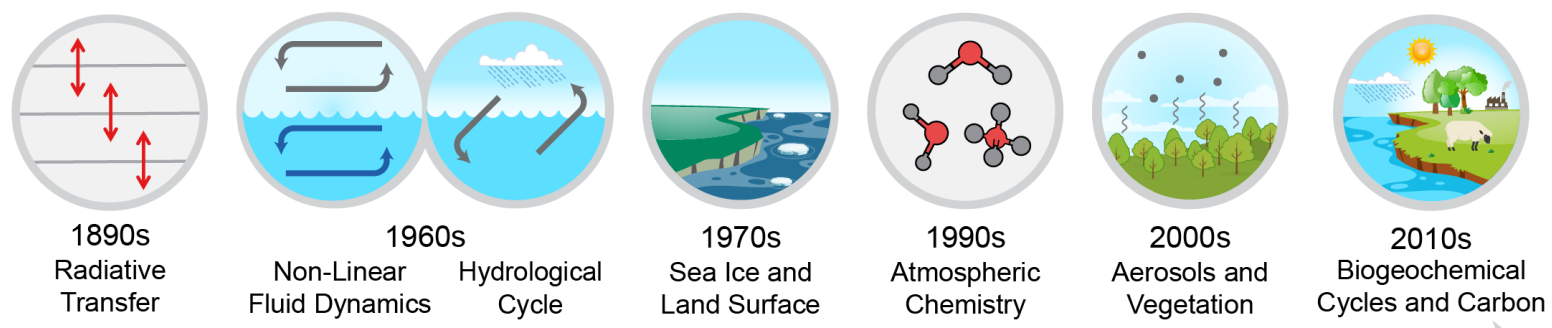

Figure 2. As scientific understanding of the climate system has evolved during the past 120 years, increasingly complex details of physics, chemistry, and biology have been incorporated into climate models. The diagram shows the decades when various processes and components of the climate system became regularly included in models. The advances in the models are based on evolving scientific understanding of global climate processes and, during the second half of the 20th century, also on the dramatic increase in computing resources. From figure 4.3 of Wuebbles and others (2017); used with permission.

\section{Coupled Model Intercomparison Project}

Advances in climate science and computing resources have led to an increase in the number of independently developed state-of-the-science models that are used to study the climate system. Still, the models and model output produced by different research institutions differ because of our imperfect knowledge of the climate system and the realities of computational and data storage limitations.

The Coupled Model Intercomparison Project (CMIP) is an international effort begun in the 1990s by multiple research organizations engaged in climate model development to produce, study, and compare climate simulations (Meehl and others, 1997; World Climate Research Programme 2019; Program for Climate Model Diagnosis \& Intercomparison [2019]). "Coupled models" refers to GCMs that include interactive atmospheric and ocean models. CMIP is led by the World Climate Research Programme, with the goal of supporting improvements in climate modeling and international climate science assessments. Within the United States, the National Oceanic and Atmospheric Administration (NOAA), the National Aeronautics and Space Administration (NASA), and the National Center for Atmospheric Research are the primary participants in the CMIP, along with the U.S. Department of Energy (DOE), which serves an important collaborative role through its Program for Climate Model Diagnosis \& Intercomparison (PCMDI; Golaz and others 2019; Program for Climate Model Diagnosis \& Intercomparison [2019]). All CMIP participants perform a predetermined suite of modeling exercises that allow for intermodel comparisons. Through these comparisons, scientists assess (1) the ability of the models to simulate past and observed aspects of the climate system, and (2) the agreement among the models in simulating difficult-to-observe aspects of the climate system. Together, such assessments advance understanding of climate processes, thereby improving confidence in the ability to simulate future changes in the climate system accurately. Beginning with the Fourth Assessment Report of the United Nations Intergovernmental Panel on Climate Change (IPCC; Intergovernmental Panel on Climate Change, 2007), the CMIP output 
became and continues to be the primary source of climate information used to project the impacts of GHG emissions.

Each successive CMIP version (termed "phase") reflects the latest scientific advances by expanding the number of physical, chemical, and biological processes explicitly represented in the models, while also incorporating improvements in the simulation of existing processes. In addition, the total number of GCM simulations has increased because more institutions are participating in the project and multiple versions of each modeling center's GCM are being released. Furthermore, the average spatial resolution and the number of vertical levels of the atmosphere used to represent the climate system have also increased with increases in computational capacity. The Coupled Model Intercomparison Project Phase 5 (CMIP5) currently provides output from more than $50 \mathrm{GCMs}$ with horizontal spatial resolutions ranging from about 30 to 200 miles (50 to 300 kilometers [km]) and vertical resolution on the order of hundreds of meters in the lower atmosphere or troposphere (from the Earth's surface to a height of 4 to 6 miles [6 to $10 \mathrm{~km}$ ]; Taylor and others, 2012). The Coupled Model Intercomparison Project Phase 6 (CMIP6), when fully completed, will likely contain twice the number of models contained in CMIP5 (Eyring and others, 2016).

\section{Climate Scenarios}

A climate scenario describes a plausible future outcome associated with a specific set of societal actions. Consequently, a climate scenario is not, strictly speaking, a prediction of the future; however, a combination of scenarios can produce a reasonable range of plausible outcomes. Climate scenarios are typically developed collaboratively by economists, experts in energy policy, climatologists, and other researchers. These scenarios attempt to capture the relationships between human choices, GHG emissions and particulate matter emissions, land use change, GHG concentrations in the atmosphere, and consequent climate changes as simulated by GCMs (Moss and others, 2010; Taylor and others, 2012). Some scenario trajectories are consistent with continued or increased dependence on fossil fuels (including large GHG emissions), whereas others reflect reductions in GHG emissions or adoption of technological advances that reduce atmospheric GHG concentrations. The resulting range of climate model projections, which use these scenarios as input for experiments-such as those defined in CMIP5 (see fig. 3)-reflects in part the uncertainty associated with future human activities and their influence on climate. Because it is extremely difficult to predict accurately how human societies will change across multiple decades or centuries, scenarios provide a means to understand the risks associated with a range of possible future actions. The utility of using scenarios in climate assessment activities as stated by the IPCC on its Scenarios Background Information web page is to "better understand uncertainties and alternative futures, in order to consider how robust different decisions or options may be under a wide range of possible futures" (Intergovernmental Panel on Climate Change, 2019).

\section{International Research Collaboration in the Development of Climate Scenarios}

The majority of the future climate projections presented in IPCC assessment reports and the USGCRP NCAs are derived from standard sets of time-dependent scenarios that the climate modeling community uses as inputs to GCMs. These scenarios are developed by the integrated assessment modeling community and, with each new generation, the scenarios have generally become more comprehensive. The original SA90 scenarios (Houghton and others, 1990) were replaced by the IS92 emission scenarios of the 1990s (Leggett and others, 1992); the IS92 
scenarios were in turn succeeded by the Special Report on Emissions Scenarios (SRES) in 2000 (Nakicenovic and Swart, 2000) and by the representative concentration pathways (RCPs) in 2010 (Moss and others, 2010; van Vuuren, Edmonds, and others, 2011).
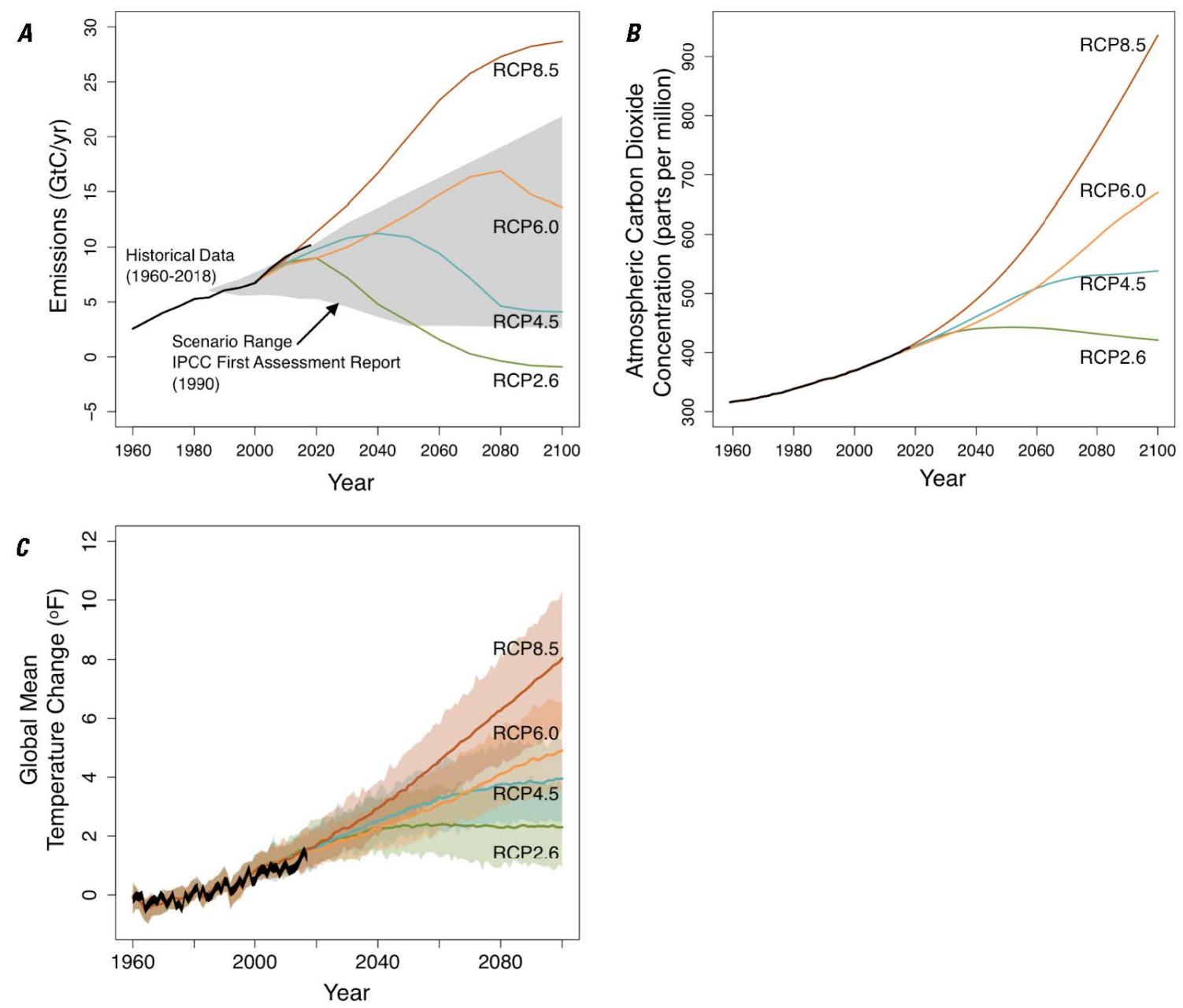

Figure 3. Graphs showing scenario trajectories of $A$, global annual carbon emissions (in gigatons of carbon per year [GtC/yr] $), B$, carbon dioxide concentration in the atmosphere (in parts per million), and $C$, projected surface air temperature change (in degrees Fahrenheit [ $\left.{ }^{\circ} \mathrm{F}\right]$ ) relative to the annual average for the period from 1950 through 1999. Observed historical values are shown as black lines, with the thickness of the line in the temperature plot depicting the amount of observational uncertainty. For comparison, the gray shading in panel $A$ represents the range of scenarios used in the first Intergovernmental Panel on Climate Change (IPCC) assessment report in 1990. The colored lines depict the means of all model results calculated for each of the representative concentration pathway (RCP) scenarios. Colored shading has been added to panel $C$ to show the full range of climate model simulation results for each scenario. The projections depicted in panel $C$ illustrate that after 2050, the scenario choice becomes the primary factor controlling variations in projected temperature. Sources of data from which the graphs were produced are the Coupled Model Intercomparison Project Phase 5 (CMIP5; Lawrence Livermore National Laboratory, 2008), Houghton and others (1990), Meinshausen and others (2011), Morice and others (2012), Hansen and others (2013), and Cowtan and Way (2014). 
Representative concentration pathways (RCPs) are the climate change scenarios used in CMIP5 (fig. 3). They are not fully integrated scenarios of future socioeconomic conditions and resulting GHG emissions. Instead, as implied in the name, the focus of the RCPs is on the total amount of GHGs - for example, carbon dioxide $\left(\mathrm{CO}_{2}\right)$, methane $\left(\mathrm{CH}_{4}\right)$, and aerosols - in the atmosphere and the resulting change in the energy balance of the Earth measured at the top of the atmosphere (van Vuuren, Edmonds, and others, 2011). The four most frequently used RCPs (RCP2.6, RCP4.5, RCP6.0, and RCP8.5) are numbered according to the change in radiative forcing ${ }^{1}$ projected to occur by 2100 relative to the preindustrial period (circa 1750; Masui and others, 2011; Riahi and others, 2011; Thomson and others, 2011; van Vuuren, Stehfest, and others, 2011). Thus, RCP2.6 represents scenarios in which global mitigation of GHG emissions is achieved and, based on modeling experiments, is still believed to be technically achievable. RCPs with higher numbers correspond to higher emissions and resulting larger global temperature change. Therefore, RCP8.5 represents a future that could be consistent with limited or no climate change mitigation policies. The two middle scenarios were chosen to be roughly equally spaced between the higher (RCP8.5) and lower (RCP2.6) scenarios.

The focus of RCPs on prescribing trajectories of GHG concentrations to drive climate models includes a deliberately wide range of future assumptions about underlying socioeconomic conditions. This range incorporates plausible global and national trends (for example, population growth, technological innovation, and the carbon intensity ${ }^{2}$ of the energy mix), that are consistent with each scenario (Moss and others, 2010). For example, whereas RCP8.5 is generally associated with higher population growth, less technological innovation, and higher carbon intensities within the global energy mix, a wide range of future socioeconomic assumptions could be consistent with its outcomes. In other words, RCP8.5 is not necessarily a business-as-usual scenario (for example, Hausfather and Peters, 2020), but neither is it a worstcase scenario. RCP8.5 is simply representative of a plausibly higher level of GHG concentrations in the atmosphere, broadly consistent with "high warming" scenarios modeled by previous global climate assessments.

Most recently, a set of shared socioeconomic pathways (SSPs; O’Neill and others, 2014) were developed that, when combined with the RCPs, provide scenarios that better meet the needs of the research groups studying impacts, adaptation, and vulnerability through a more explicit description of socioeconomic inputs (that is, policy choices). The peer-reviewed climate literature still relies heavily on the RCPs, but this matrixed approach to scenarios (RCPs plus SSPs) is currently being used in CMIP6, the latest phase of the CMIP (Eyring and others, 2016) and will likely be used more extensively in the future.

Because scenarios are developed in a risk-based framework with a high degree of uncertainty about future societal developments, individual RCP scenarios have not been assigned a formal likelihood of occurrence. Therefore, in the current framework used by the IPCC and the

\footnotetext{
${ }^{1}$ In accordance with the basic laws of thermodynamics, as Earth absorbs energy from the sun, it must eventually emit an equal amount of energy to space. The difference between incoming (that is, sunlight-sourced) energy and outgoing energy radiated back to space because of a change in atmospheric composition or solar input is known as radiative forcing $(\mathrm{RF})$ and is defined in units of watts per square meter $\left(\mathrm{W} / \mathrm{m}^{2}\right)$. In the same way as applying a pushing force to a physical object will cause it to become unbalanced and move, a climate forcing factor will change the climate system. When forcings result in incoming energy being greater than outgoing energy, the planet will warm (that is, have positive RF).

${ }^{2}$ Carbon intensity is a metric to understand the overall $\mathrm{CO}_{2}$ emissions for a given mix of energy resources. For example, an energy mix that comprises coal and oil exclusively would have a higher "carbon intensity" than an energy mix that is composed exclusively of natural gas and nuclear energy.
} 
NCA, each emissions scenario is considered to be a plausible outcome. As the choice of scenario constrains the magnitude of future projected changes, best scientific practice generally involves quantifying future change and corresponding impacts over a range of scenarios that reflect the uncertainty in the consequences of human choices in the coming century. Without such practices, or if scenarios are developed that are insufficiently representative of a range of plausible future conditions, there is an increased chance of overconfident decision making, potentially leading to a greater risk of unacceptable damages or even catastrophic outcomes. Figure 3A illustrates an example of what, in hindsight, could now be considered a set of scenarios that were not broad enough to cover all plausible outcomes. The envelope of GHG emissions trajectories from IPCC's first assessment report in 1990 are depicted in the gray shaded region. The observed emissions (solid black line) in the intervening three decades have actually exceeded the upper scenario range, suggesting that decision makers were operating under a less accurate risk characterization, because at the time they were not able to consider the full plausible range of emissions (and, therefore, climate) trajectories when developing response strategies.

Figure 3 also shows each RCP scenario's modeled 21st century trajectory of carbon emissions (panel $A$ ), atmospheric $\mathrm{CO}_{2}$ concentrations (panel $B$ ), and resulting global air temperature changes (panel $C$ ). By the second half of the century, the differences between the RCP scenarios are driving the majority of the differences in simulated temperature change, although uncertainties associated with climate variability, climate feedback processes, and imperfect knowledge of the climate system also contribute to the total range of projected temperature change. Note that the $\mathrm{CO}_{2}$ concentrations (panel $B$ ) and resulting temperature changes (panel $C$ ) show continuing increases throughout the 21 st century for all but the RCP2.6 scenario. In contrast, carbon emissions (panel $A$ ), which are the driving agents of these scenario trajectories, are shown to decrease or reach stabilizing levels in all scenarios by 2100 . For time periods beyond this, a limited set of model experiments were performed under the extended concentration pathway (ECP) scenarios, which extend the RCPs through 2300 (Meinshausen and others, 2011).

In keeping with the principle that scenarios should represent a plausible future (even if no statement of the likelihood of the scenario is given), these ECPs assume that even under RCP8.5, there is a finite amount of GHGs that can be emitted in the future. In other words, no scenario assumes indefinite growth in GHG emissions in perpetuity. So, although RCP8.5 shows continued increases in emissions throughout this century, the economic, technological, and societal assumptions embedded in this scenario also suggest that emissions would stop increasing by 2100 , followed by a decline to near-zero emissions levels around 2250 . Importantly, because most GHGs have a multiyear to multicentury residence time in the atmosphere, atmospheric concentrations of GHG will not stop increasing until emissions reach near-zero levels. By extension, barring some technological breakthrough to remove large quantities of GHGs from the atmosphere, air temperatures would continue to increase until anthropogenic GHG emissions are negligible, but would likely stabilize soon after this time (Solomon and others, 2009). This all indicates that the range of uncertainty in projected temperatures (and in most other climate impacts), rather than continuing to increase as might be assumed in figure $3 \mathrm{C}$, will stabilize at some point beyond 2100 .

The effects of these particular GHG emissions scenarios (fig. 3) on global climate become most evident around 2050, when temperature projections based on each scenario begin to diverge substantially. With large sustained reductions in GHG emissions (for example, those consistent with the RCP2.6 set of scenarios), the increase in global annual average air 
temperature relative to preindustrial times could be limited to less than 3.6 degrees Fahrenheit $\left({ }^{\circ} \mathrm{F}\right)\left[2\right.$ degrees Celsius $\left[{ }^{\circ} \mathrm{C}\right]$ ). Without significant $\mathrm{GHG}$ reductions (for example, following a set of scenarios like RCP8.5), the increase in global annual average air temperature could reach $9^{\circ} \mathrm{F}\left(5^{\circ} \mathrm{C}\right)$ or more by the end of this century. Because the components of the Earth's climate system respond to the effects of atmospheric GHG concentrations over different time scales, some responses, such as global mean sea level rise, would continue (at least to some degree) for centuries, regardless of the future scenario (Solomon and others, 2009; Collins and others, 2013).

\section{Range of Air Temperature Response for the Conterminous United States}

The response of the global climate system to GHG emissions varies both temporally and spatially. To inform natural resource management strategies across the country, it is useful to consider downscaled ${ }^{3}$ air temperature projections for the United States (fig. 4). Compared with RCP-driven projections of global annual average air temperatures (fig. 3), by the year 2095 the projected air temperature changes over the United States range from $1^{\circ} \mathrm{F}\left(0.6^{\circ} \mathrm{C}\right)$ warmer under RCP2.6, to $3{ }^{\circ} \mathrm{F}\left(1.7^{\circ} \mathrm{C}\right)$ warmer under RCP8.5 (fig. 4). Figures 4A-D illustrate the different multimodel ensemble projections of warming under each of the RCPs and show that the range of the spread of the individual models is similar among the RCPs. Going a step further, Figure $4 E$ illustrates that (relative to the base period of 1950 through 1999), after the cooling associated with the eruption of Pinatubo around 1992, the ensemble mean changes in response to GHG forcing under all the RCPs are statistically significant relative to the spread of the individual models.

Figures 3 and 4 illustrate the difference in the range of projected global air temperature changes versus the range projected for the conterminous United States only. Air temperature changes over North America are expected to be larger than the global average because land warms faster - and to a greater extent - than do oceans (and the Earth's surface is greater than $70 \%$ ocean).

\footnotetext{
${ }^{3}$ Downscaling is the process of translating the lower spatial resolution output from the CMIP GCMs to a higher spatial resolution through regional climate models or statistical methods. Downscaling is used to provide more detail about local climate change impacts that capture the fine-scale influence of important features, such as mountains, coastlines, and islands. Like many climate researchers worldwide, DOI and USGS scientists use downscaled climate data extensively in climate impact assessments.
} 
Figure 4. (Figure on next page) Graphs showing projected changes in mean-annual air temperature relative to the base period of 1950 through 1999 under the four representative concentration pathways (RCPs) for the conterminous United States (panels $A$ through $D$ ) and the standard error of the mean for the individual model runs for each RCP (panel $E$ ). Each plot in panels $A$ through $D$ includes results for multiple, individual model runs (shown in gray; the total number of runs within each scenario is indicated by $\mathrm{N}$ ) and the solid black lines represent the multimodel ensemble means of the $\mathrm{N}$ runs. The differences in the number of individual model runs (that is, the $\mathrm{N}$ values) reflects the effort by the Coupled Model Intercomparison Project (CMIP) modeling centers to simulate the various RCPs. The gray band in panel $E$ indicates the range over which the ensemble mean differences are not statistically significant relative to the spread in the individual simulations for a given year. Ensemble mean differences that fall outside the gray band are statistically significant at the $95 \%$ confidence level (Deser and others, 2012). The mean-annual data were derived by averaging statistically downscaled 1-degree gridded monthly data sets over land in North America between $24.5^{\circ} \mathrm{N}$. and $53.5^{\circ} \mathrm{N}$. latitude. The monthly data were obtained from the Downscaled CMIP3 and CMIP5 Climate and Hydrology Projections archive at https://gdo-dcp.ucllnl.org/downscaled_cmip_projections/. The Bureau of Reclamation and the U.S. Geological Survey are collaborators in the projections project. 

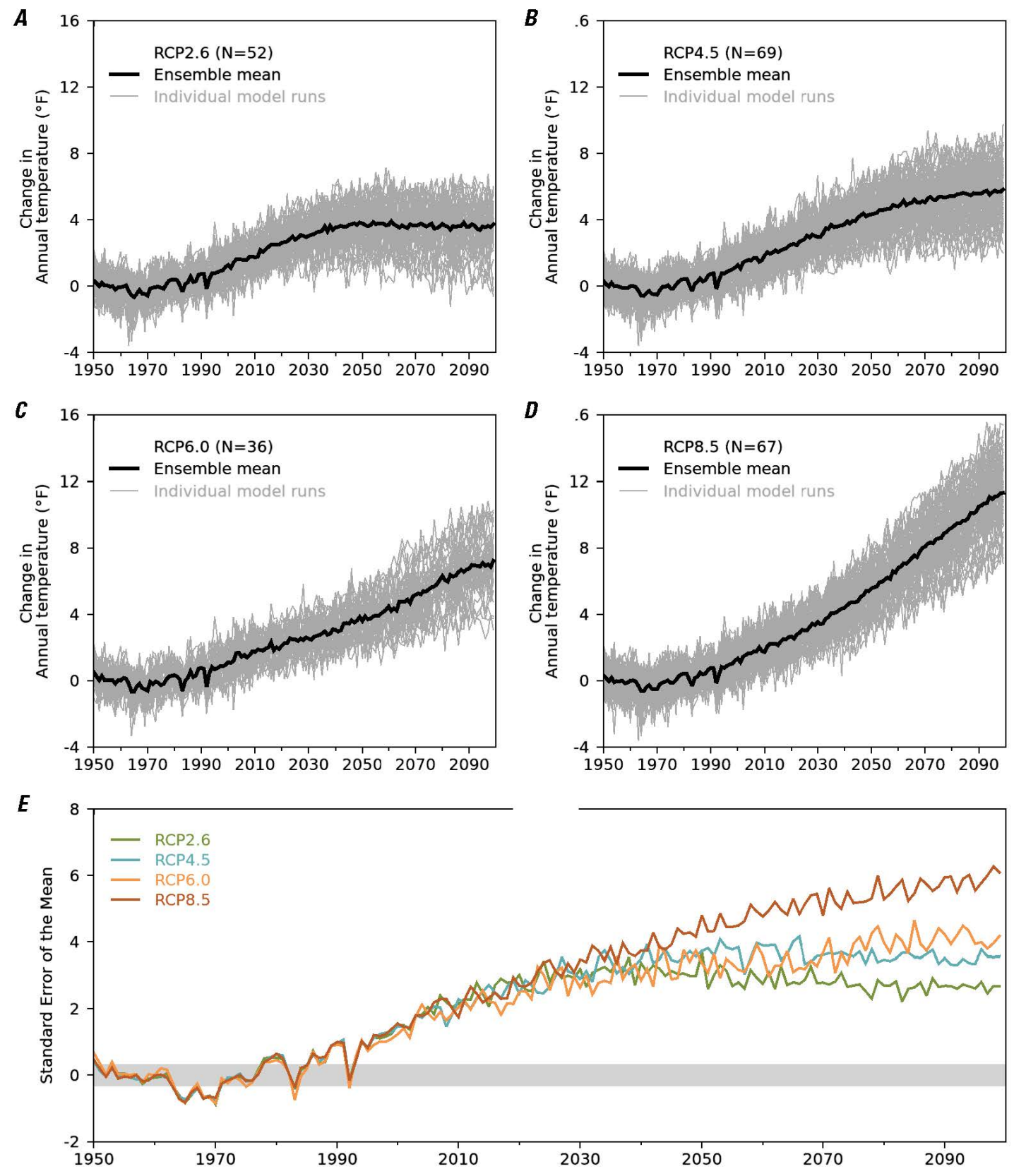

\section{Uncertainty in Climate Projections and Model Accuracy}

Uncertainty in century-scale projections of Earth's climate stems from three primary sources. These are (1) the natural variability in the climate system; (2) imperfect scientific knowledge about the response of the climate system to changes in GHG emissions (which manifests itself in structural differences in the ways that each climate model represents processes, such as cloud formation and land-atmosphere feedbacks); and (3) uncertainty about future trajectories of GHG emissions resulting from future human actions and policy decisions.

In the near term (years to decades), natural climate variability (shown in green and labeled as "internal variability" in fig. 5) is the largest source of uncertainty in climate projections. As a general practice in climate assessments, uncertainty from natural variability is often addressed by assuming that the future will have at least the same range of natural 
variability over the medium to long time periods, and possibly a wider range than has been observed historically (National Academies of Sciences, Engineering, and Medicine, 2016).

Over multidecadal timescales (that is, approximately the next 30 to 50 years), uncertainties among climate model outputs tend to be most influenced by our imperfect scientific knowledge of the climate system (scientific uncertainty, shown in blue in fig. 5; Hawkins and Sutton, 2009). The climate models used in national and global assessments simulate plausible and realistic representations of Earth's climate, but differences in how the models are developed and configured causes variation in model outputs and ultimately affects the sensitivity of any given model to changes in atmospheric GHG concentrations. The IPCC's use of the CMIP and the Paleoclimate Modelling Intercomparison Project (PMIP) results illustrates one method to account for this scientific uncertainty through the use of a range of climate models to represent a broader range of simulated climates.

Over longer timescales (that is, approximately the next 60 to 100 years), human actions and decisions that affect global GHG emissions (shown in orange in fig. 5) are the largest source of uncertainty in climate projections (that is, scenario uncertainty). Atmospheric concentrations of GHG in the near- and mid-term are primarily determined by current emissions and the average time it takes for emitted molecules to break down chemically in the atmosphere. In the long term, however, human choices regarding economic development, changes in technology, and population trends will determine emission levels. To account for this uncertainty, most global and regional climate assessments use climate model results from a range of emissions scenarios.

Which of these sources of uncertainty - natural variability, scientific uncertainty, or scenario uncertainty - is most important in a policymaking context depends on the timeframe and the climate variables that are relevant to the decision makers. As one looks farther into the future to inform a particular decision, the difference between the range of emissions scenarios is greater because of the increase in the range of what could reasonably be considered plausible. For global air temperature, the scenario uncertainty (that is, the orange area in fig. 5) becomes an increasingly greater factor in determining the magnitude and patterns of future warming about 25 years after the scenario begins. Importantly though, for some climate-related variables, most notably sea level rise, there is significant inertia in the physical processes driving the response to GHG emissions. This will cause a delayed response relative to a rise in GHG emissions, meaning that scenario uncertainty may not become the largest source of uncertainty for many decades beyond 2100 as the climate system slowly adjusts to past emissions. In summary, even though natural variability and scientific uncertainty will continue to be factors in determining the uncertainty of the overall projection, with a few important exceptions, most of the difference between the present climate and the climate at the end of the century and beyond will be determined by decisions made by policymakers today and during the next few decades. The further out in time we look, the greater the influence these human choices will have on the magnitude of future warming. 


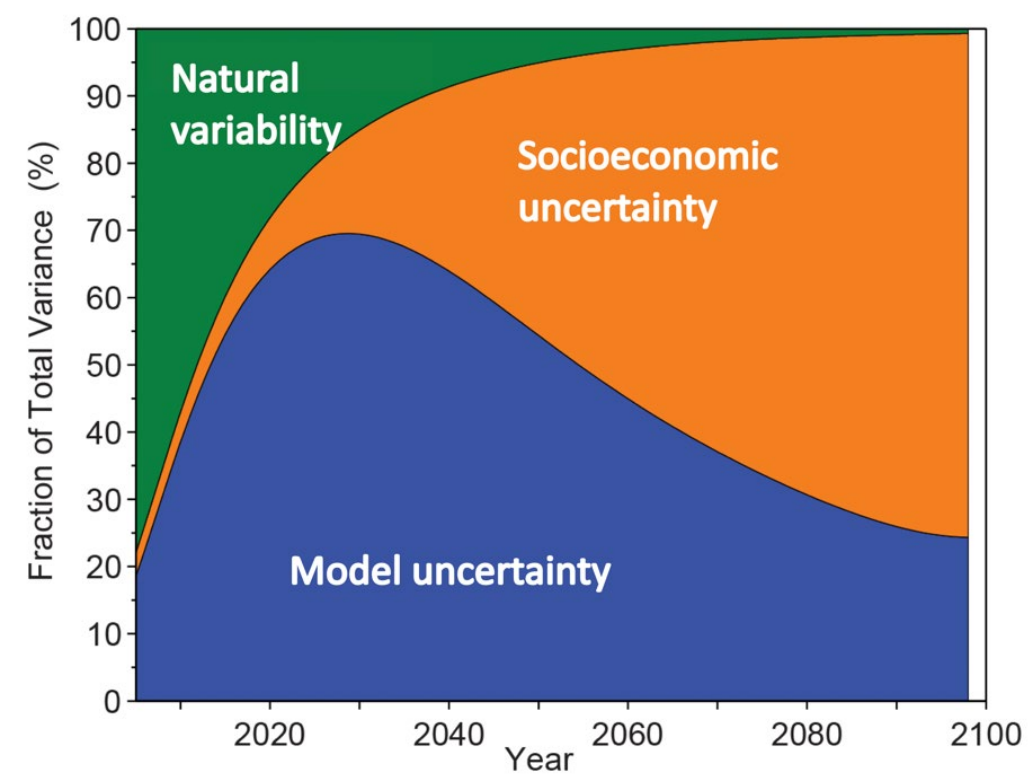

Figure 5. Graph showing the fraction of total variance in decadal mean surface air temperature predictions explained by the three components of total uncertainty for the conterminous United States (similar results are seen for Hawai'i and Alaska, not shown). Orange regions represent uncertainty associated with human decisions (socioeconomic uncertainty), blue regions represent model (also referred to as scientific or structural) uncertainty, and green regions represent uncertainty caused by natural variability of the climate system. In interpreting this figure, it is important to remember that it shows the relative contribution of each source of uncertainty through time; the total amount of uncertainty, however, increases as time progresses. From figure 4.5 of Wuebbles and others (2017), which was based on Hawkins and Sutton (2009) @ American Meteorological Society; used with permission.

Evaluating the quality and accuracy (that is, "skill") of climate model simulations is not a straightforward process (Randall and others, 2007). Climate simulations such as those performed as part of the CMIP are not attempting to replicate actual day-to-day weather patterns. Although the output from each climate model simulation includes internal variability or "weather" under the same constraints (or boundary conditions) as the Earth's climate system, there is no reason for the simulated weather to match the actual observed weather conditions for a particular day in the past or the future, other than by chance. Thus a skillful climate model would be able to reproduce the observed past, present, or future climate (that is, the statistical properties of meteorological variables), given the correct boundary conditions, such as atmospheric GHG concentrations, but there is no equivalent expectation for a skillful climate model to be able to reproduce the observed past, present, or future day-to-day weather. The CMIP results in figure 1 and figure $3 \mathrm{C}$ demonstrate that the current generation of GCMs is able to reproduce the evolving historical trend in global surface air temperatures that is a result of large-scale changes in the Earth's energy balance (primarily human emissions of GHGs and aerosols, and volcanic eruptions). But, as expected, the model results do not exactly match the year-to-year variations in global temperatures because those variations are dominated by short-term weather patterns and fluctuations in the climate system. 


\section{Representative Concentration Pathways in a Policymaking Context}

As simulated in CMIP5, all the RCP scenarios result in similar global temperature (fig. 3C) and sea level rise outcomes for the next few decades. By mid-century and beyond, however, projected differences in results between the RCP scenarios would have a substantial effect on the climate and impact outcomes. Looking at the range of outcomes across scenarios for analyses of impacts, adaptation, and vulnerability allows for an evaluation of both short- and long-term risks and opportunities for the United States. For example, comparing outcomes under RCP 8.5 with those of RCP2.6 not only captures a range of uncertainties and plausible futures, but also allows agencies the opportunity to implement decision-making processes that reflect their risk tolerance to a wide range of plausible outcomes. Comparing outcomes under these two pathways shows the degree to which significant emissions mitigation at the global scale can prevent some impacts, while also allowing decision makers to assess the robustness of adaptation strategies to diminish the risks that are present even under a scenario with less warming.

\section{Roles of the U.S. Geological Survey in Climate Science}

The USGS has a long history of working on scientific questions related to the impact of climate change on natural resources. As early as 1986, USGS scientists were publishing results showing the beginnings of rapid permafrost thaw in the Alaskan Arctic (Lachenbruch and Marshall, 1986). The USGS's work in climate science has been focused on the following:

- Examining the geologic record to reconstruct and understand the Earth's climate in the past;

- Integrating paleoclimate reconstructions with climate modeling experiments;

- Providing test cases and boundary conditions for assessing the skillfulness of climate simulations of past climates (such as those of the Pliocene and early and mid-Holocene Epochs) through participation in the PMIP (a parallel component of the CMIP);

- Using GCM output that has been downscaled (to achieve higher spatial resolution) for making regional and local climate projections;

- Using both original and downscaled GCM output to examine the impacts of climate change on natural resources; and

- Working with the management community to assist with adaptation planning.

The USGS does not develop any of the GCMs used by the international community. The USGS primarily uses climate model output developed as part of internationally agreed-upon structured experiments (for example, CMIPs) and carried out by modeling groups around the world. As part of its routine science practices, the USGS will continue to:

- Review the state of knowledge of climate science;

- Develop and maintain best practices in using GCMs, ESMs, and regional climate models (including efforts to evaluate the skill of downscaled climate model projections) to project climate change impacts; 
- Provide data and interpretations of potential impacts based upon the best available science to the DOI and other stakeholders at the temporal and spatial scales relevant for policymaking; and

- Provide and improve paleoclimate data and boundary conditions to independently assess the ability of climate models to simulate known past climate states.

Collecting, analyzing, and interpreting historical observations of how Earth's climate has changed, assessing the scientific basis for climate change, projecting future climate change and its impacts and risks on a global scale, and identifying options for adaptation and mitigation are also carried out by a number of entities other than the USGS. These include, but are not limited to-

- Other DOI bureaus, offices, and programs;

- Other Federal Departments - for example, DOE, NASA, NOAA, U.S. Department of Agriculture, U.S. Department of Transportation, and U.S. Environmental Protection Agency;

- USGCRP, which is legally mandated to, among other things, provide regular assessments of the scientific understanding of climate change and how it affects human and natural systems;

- National Academies of Sciences, Engineering, and Medicine;

- International entities, such as the IPCC; and

- Academia - for example, University Corporation for Atmospheric Research (UCAR).

No single entity is adequately equipped to carry out all this work. Continued support for ongoing collaborations among these entities - including the USGS - is essential if policymakers are to be provided with the best available science.

\section{Federal Government's Need for Climate Science and Climate Impact Science}

DOI bureaus and other Federal Government agencies that have legally mandated missions to manage natural resources and human systems for future generations use climate information-including paleoclimate science, historical and current observations, and projections - to help meet their missions. The National Park Service, Bureau of Land Management (BLM), and U.S. Fish and Wildlife Service all protect and manage landscapes and habitats for the long-term conservation of species. The BLM and the Forest Service also manage lands and natural resources for the benefit of the public, including the extractive industries. The Bureau of Reclamation manages, develops, and protects water and related resources in the interest of the American public. The Bureau of Indian Affairs carries out the responsibility to protect and improve the trust assets of American Indians, Indian tribes, and Alaska Natives.

Natural resources and human systems are affected by climate and climate change in various ways across a range of time scales. To decrease the chance of unanticipated impacts on the resources they manage, managers and policymakers benefit from an understanding of how climate could evolve on timescales spanning decades to centuries. Climate changes, both observed and projected, have implications for the missions of all Government agencies and the 
resources they manage. Some of the management challenges related to climate change include but are not limited to-

- Wildfire and prescribed fire regimes;

- Preservation and restoration of wildlife habitat and native species;

- Invasive species;

- Fish and wildlife populations;

- Water availability and quality;

- Landscape change; and

- Wildlife disease.

Collectively, DOI bureaus and other Federal natural resource agencies with missions related to natural resources face tremendous challenges and opportunities in managing landscapes and infrastructure, planning for future changes in resource availability and integrity, and investing resources wisely now to meet future needs and conditions. Given the long-term consequences associated with many resource management decisions and actions, Federal agencies also use long-term (50 to 100 years or longer) climate projections to obtain a more comprehensive assessment of future long-term risks.

\section{How U.S. Geological Survey Climate Science Is Provided to the Department of the Interior to Inform Policymaking}

Because the USGS provides climate impact and adaptation science for use in a variety of DOI-related policymaking and decision-making processes, it is necessary for the USGS to follow practices that ensure that its science is the best and most up-to-date possible. At the same time, it remains the responsibility of the DOI and external stakeholders to decide how they will factor climate change information and science from the USGS and other sources into their decision making.

The following aspects will be considered when the USGS works with climate projections and impact analyses:

- Potential future impacts will be modeled assuming a range of scenarios whenever feasible, such as across the entire range of RCP-based scenarios. On decision-relevant timescales greater than a few decades, the use of multiple emissions scenarios addresses the largest source of uncertainty in understanding the potential magnitude of future warming.

- When feasible, multiple climate models (that is, a multimodel ensemble) representative of the entire range of the CMIP output over the area of interest will be used to characterize scientific uncertainty. The specific multimodel ensemble used may vary with the impact questions at hand. For example, some models have more sophisticated representations of ocean or land surface carbon or sea ice than do others.

- Climate scenarios and models that project 100 years or more into the future can be useful for understanding climate impacts that are sensitive to inertia in the Earth system. 
The decision whether to employ such long-term scenarios to inform policymaking will give special consideration to whether the decision context is sensitive to-

- Delayed climate change impacts arising from past GHG emissions;

- Climate change impacts that are potentially irreversible;

- Crossing any thresholds occurring on these timescales that may cause major impacts (Collins and others, 2013).

- Natural climate variability, particularly in projections from a few years to a few decades, will be emphasized as an important source of near-term uncertainty.

- Impact assessments should:

- Consider the entire range of available scenarios;

- Use a range of widely tested models;

- Cover timescales ranging from the near term out to a century or longer.

- USGS studies will articulate clearly the uncertainties in their analyses, including how the uncertainties evolve over the modeled time period and the implications of these uncertainties for interpreting the results.

\section{Ongoing Efforts by the U.S. Geological Survey to Improve Understanding and Communication of Climate Science}

To ensure that the USGS continues to rely on the best approaches and techniques when developing and delivering climate model impacts output, USGS researchers will-

- Continue to follow established fundamental science practices.

- Stay abreast of new and developing climate datasets that are vetted by national and international modeling efforts.

- Where possible, explicitly evaluate model-simulated historical climate trends against observations over the area of interest, endeavoring to describe uncertainties in model projections.

- Clearly state the limitations of the science as it relates to climate information.

- Ensure that both the climate data used and the projections based on the data continue to receive rigorous peer review.

The USGS will continue to work regularly with the international research community to evaluate and improve our practices and techniques for collecting, developing, and using climate data, including historic observations and projections of future conditions, with a view to informing management decisions for the DOI and external stakeholders.

The USGS will report on significant changes in climate science and advancements in best practices to the DOI at least once every 5 years. As appropriate, any specific future-looking impact analyses by the USGS may be revised to incorporate new data, new best practices, and new interpretations. 


\section{References Cited}

Blunden, J., and Arndt, D.S., eds., 2019, State of the climate in 2018: Special Supplement to the Bulletin of the American Meteorological Society, v. 100, no. 9, p. Si-S305, accessed December 26, 2019, at https://doi.org/10.1175/2019BAMSStateoftheClimate.1.

Clarke, L., Nichols, L., Vallario, R., Hejazi, M., Horing, J., Janetos, A.C., Mach, K., Mastrandrea, M., Orr, M., Preston, B.L., Reed, P., Sands, R.D., and White, D.D., 2018, Sector interactions, multiple stressors, and complex systems, chap. 17 of D.R. Reidmiller, C.W. Avery, D.R. Easterling, K.E. Kunkel, K.L.M. Lewis, T. K. Maycock, and B.C. Stewart, eds., Impacts, risks, and adaptation in the United States-Fourth national climate assessment, volume II: Washington, D.C., U.S. Global Change Research Program, p. 638-668, accessed December 26, 2019, at https://nca2018.globalchange.gov/chapter/17/.

Collins, M., Knutti, R., Arblaster, J., Dufresne, J.-L., Fichefet, T., Friedlingstein, P., Gao, X., Gutowski, W.J., Johns, T., Krinner, G., Shongwe, M., Tebaldi, C., Weaver, A.J., and Wehner, M., 2013, Long-term climate change-Projections, commitments and irreversibility, chap. 12 of T.F. Stocker, D. Qin, G.-K. Plattner, M. Tignor, S.K. Allen, J. Boschung, A. Nauels, Y. Xia, V. Bex, and P.M. Midgley, eds., Climate change 2013-The physical science basis. Contribution of Working Group I to the Fifth Assessment Report of the Intergovernmental Panel on Climate Change: Cambridge, United Kingdom, and New York, N.Y., Cambridge University Press, p. 1029-1136, accessed December 26, 2019, at https://www.ipcc.ch/site/assets/uploads/2018/02/WG1AR5_Chapter12_FINAL.pdf

Cowtan, K., and Way, R.G., 2014, Coverage bias in the HadCRUT4 temperature series and its impact on recent temperature trends: Quarterly Journal of the Royal Meteorological Society, v. 140 , no. 683, p. 1935-1944, accessed December 26, 2019, at https://doi.org/10.1002/qj.2297.

Deser, C., Phillips, A., Bourdette, V., and Teng, H., 2012, Uncertainty in climate change projections - The role of internal variability: Climate Dynamics, v. 38, nos. 3-4, p. 527-546, accessed December 26, 2019, at https://doi.org/10.1007/s00382-010-0977-x.

Eyring, V., Bony, S., Meehl, G.A., Senior, C.A., Stevens, B., Stouffer, R.J., and Taylor, K.E., 2016, Overview of the Coupled Model Intercomparison Project Phase 6 (CMIP6) experimental design and organization: Geoscientific Model Development, v. 9, no. 5, p. 1937-1958, accessed December 26, 2019, at https://doi.org/10.5194/gmd-9-1937-2016.

Flato, G.J., Marotzke, J., Abiodun, B., Braconnot, P., Chou, S.C., Collins, W., Cox, P., Driouech, F., Emori, S., Eyring, V., Forest, C., Gleckler, P., Guilyardi, E., Jakob, C., Kattsov, V., Reason, C., and Rummukainen, M., 2013, Evaluation of climate models, chap. 9 of T.F. Stocker, D. Qin, G.-K. Plattner, M. Tignor, S.K. Allen, J. Boschung, A. Nauels, Y. Xia, V. Bex, and P.M. Midgley, eds., Climate change 2013-The physical science basis.

Contribution of Working Group I to the Fifth Assessment Report of the Intergovernmental Panel on Climate Change: Cambridge, United Kingdom, and New York, N.Y., Cambridge University Press, p. 741-866, accessed December 26, 2019, at https://www.ipcc.ch/report/ar5/wg1/evaluation-of-climate-models/. 
Golaz, J.C., Caldwell, P.M., Van Roekel, L.P., Petersen, M.R., Tang, Q., Wolfe, J.D., Abeshu, G., Anantharaj, V., Asay-Davis, X.S., Bader, D.C., Baldwin, S.A., Bisht, G., Bogenschutz, P.A., Branstetter, M., Brunke, M.A., Brus, S.R., Burrows, S.M., Cameron-Smith, P.J., Donahue, A.S., Deakin, M., Easter, R.C., Evans, K.J., Feng, Y., Flanner, M., Foucar, J.G., Fyke, J.G., Griffin, B.M., Hannay, C., Harrop, B.E., Hoffman, M.J., Hunke, E.C., Jacob, R.L., Jacobsen, D.W., Jeffery, N., Jones, P.W., Keen, N.D., Klein, S.A., Larson, V.E., Leung, L.R., Li, H.-Y., Lin, W., Lipscomb, W.H., Ma, P.-L., Mahajan, S., Maltrud, M.E., Mametjanov, A., McClean, J.L., McCoy, R.B., Neale, R.B., Price, S.F., Qian, Y., Rasch, P.J., Reeves Eyre, J.E.J., Riley, W.J., Ringler, T.D., Roberts, A.F., Roesler, E.L., Salinger, A.G., Shaheen, Z., Shi, X., Singh, B., Tang, J., Taylor, M.A., Thornton, P.E., Turner, A.K., Veneziani, M., Wan, H., Wang, H., Wang, S., Williams, D.N., Wolfram, P.J., Worley, P.H., Xie, S., Yang, Y., Yoon, J.-H., Zelinka, M.D., Zender, C.S., Zeng, X., Zhang, C., Zhang, K., Zhang, Y., Zheng, X., Zhou, T., and Zhu, Q., 2019, The DOE E3SM Coupled Model version 1-Overview and evaluation at standard resolution: Journal of Advances in Modeling Earth Systems, v. 11, no. 7, p. 2089-2129, accessed December 26, 2019, at https://doi.org/10.1029/2018MS001603.

Hansen, J., Kharecha, P., Sato, M., Masson-Delmotte, V., Ackerman, F., Beerling, D.J., Hearty, P.J., Hoegh-Guldberg, O., Hsu, S.-L., Parmesan, C., Rockstrom, J., Rohling, E.J., Sachs, J., Smith, P., Steffen, K., Van Susteren, L., von Schuckmann, K., and Zachos, J.C., 2013, Assessing "dangerous climate change"-Required reduction of carbon emissions to protect young people, future generations and nature: PLoS One, v. 8, no. 12, article e81648, accessed December 26, 2019, at https://doi.org/10.1371/journal.pone.0081648.

Hausfather, A., and Peters, G.P., 2020, Emissions - The 'business as usual' story is misleading. Nature, v. 577, p. 618-620, accessed February 26, 2020, at https://www.nature.com/articles/d41586-020-00177-3.

Hausfather, Z., Drake, H.F., Abbott, T., and Schmidt, G.A., 2020, Evaluating the performance of past climate model projections: Geophysical Research Letters, v. 47, no. 1, accessed March 4, 2019, at https://doi.org/10.1029/2019GL085378.

Hawkins, E., and Sutton, R., 2009, The potential to narrow uncertainty in regional climate predictions: Bulletin of the American Meteorological Society, v. 90, no. 8, p. 1095-1107, accessed December 26, 2019, at https://doi.org/10.1175/2009BAMS2607.1.

Hawkins, E., and Sutton, R., 2012, Time of emergence of climate signals: Geophysical Research Letters, v. 39, no. 1, p. 1-6, accessed December 26, 2019, at https://doi.org/10.1029/2011GL050087.

Hawkins, E., Smith, R.S., Gregory, J.M., and Stainforth, D.A., 2016, Irreducible uncertainty in near-term climate projections: Climate Dynamics, v. 46, no. 11-12, p. 3807-3819, accessed December 26, 2019, at https://doi.org/10.1007/s00382-015-2806-8.

Hayhoe, K., Edmonds, J., Kopp, R.E., LeGrande, A.N., Sanderson, B.M., Wehner, M.F., and Wuebbles, D.J., 2017, Climate models, scenarios, and projections, chap. 4 of D.J. Wuebbles, D.W. Fahey, K.A. Hibbard, D.J. Dokken, B.C. Stewart, and T.K. Maycock, eds., Climate science special report—Fourth national climate assessment, volume I: Washington, D.C., U.S. Global Change Research Program, p. 133-160, accessed December 26, 2019, at https://doi.org/10.7930/J0J964J6. 
Hostetler, S.W., Bartlein, P.J., and Alder, J.R., 2018, Atmospheric and surface climate associated with 1986-2013 wildfires in North America: Journal of Geophysical ResearchBiogeosciences, v. 123, no. 5, p. 1588-1609, accessed December 26, 2019, at https://doi.org/10.1029/2017JG004195.

Houghton, J.T., Jenkins, G.J., and Ephraums, J.L., eds., 1990, Climate change-The IPCC scientific assessment: Cambridge, United Kingdom, and New York, N.Y., Cambridge University Press, 339 p. plus 8 appendixes, accessed December 26, 2019, at https://www.ipcc.ch/report/ar1/wg1/.

Intergovernmental Panel on Climate Change, 2007, Climate change 2007-Synthesis report. Contribution of Working Groups I, II and III to the Fourth Assessment Report of the Intergovernmental Panel on Climate Change [Core Writing Team, R.K. Pachauri, and A. Reisinger (eds.)]: Geneva, Switzerland, Intergovernmental Panel on Climate Change, 104 p., accessed April 23, 2020, at https://www.ipcc.ch/report/ar4/syr/.

Intergovernmental Panel on Climate Change, 2019, Scenario process for AR5-Scenarios background information: Intergovernmental Panel on Climate Change Data Distribution Centre web page, accessed December 26, 2019, at https://sedac.ciesin.columbia.edu/ddc/ar5_scenario_process/scenario_background.html. Lachenbruch, A.H., and Marshall, B.V., 1986, Changing climate-Geothermal evidence from permafrost in the Alaskan Arctic: Science, v. 234, no. 4777, p. 689-696, accessed December 26, 2019, at https://doi.org/10.1126/science.234.4777.689.

Lawrence Livermore National Laboratory, 2008, CMIP5-Coupled Model Intercomparison Project Phase 5-Overview: Lawrence Livermore National Laboratory, Program for Climate Model Diagnosis \& Intercomparison web page, accessed February 20, 2020, at https://pcmdi.llnl.gov/mips/cmip5/.

Leggett, J., Pepper, W.J., Swart, R.J., Edmonds, J., Filho, L.G.M., Mintzer, I., Wang, M.-X., and Watson, J., 1992, Emissions scenarios for the IPCC-An update: Cambridge, United Kingdom, and New York, N.Y., Cambridge University Press, 95 p.

Martinich, J., DeAngelo, B.J., Diaz, D., Ekwurzel, B., Franco, G., Frisch, C., McFarland, J., and O’Neill, B., 2018, Reducing risks through emissions mitigation, chap. 29 of D.R. Reidmiller, C.W. Avery, D.R. Easterling, K.E. Kunkel, K.L.M. Lewis, T.K. Maycock, and B.C. Stewart, eds., Impacts, risks, and adaptation in the United States-Fourth national climate assessment, volume II: Washington, D.C., U.S. Global Change Research Program, p. 1346-1386, accessed December 26, 2019, at https://nca2018.globalchange.gov/chapter/29/.

Masui, T., Matsumoto, K., Hijioka, Y., Kinoshita, T., Nozawa, T., Ishiwatari, S., Kato, E., Shukla, P.R., Yamagata, Y., and Kainuma, M., 2011, An emission pathway for stabilization at $6 \mathrm{Wm}^{-2}$ radiative forcing: Climatic Change, v. 109, no. 1-2, p. 59-76, accessed December 26, 2019, at https://doi.org/10.1007/s10584-011-0150-5.

Meehl, G.A., Boer, G.J., Covey, C., Latif, M., and Stouffer, R.J., 1997, Intercomparison makes for a better climate model: Eos, Transactions, American Geophysical Union, v. 78, no. 41, p. 445-451, accessed December 26, 2019, at https://doi.org/10.1029/97EO00276.

Meinshausen, M., Smith, S.J., Calvin, K., Daniel, J.S., Kainuma, M.L.T., Lamarque, J.-F., Matsumoto, K., Montzka, S.A., Raper, S.C.B., Riahi, K., Thomson, A., Velders, G.J.M., and van Vuuren, D.P.P., 2011, The RCP greenhouse gas concentrations and their extensions from 1765 to 2300: Climatic Change, v. 109, no. 1, p. 213-241, accessed December 26, 2019, at https://doi.org/10.1007/s10584-011-0156-z. 
Morice, C.P., Kennedy, J.J., Rayner, N.A., and Jones, P.D., 2012, Quantifying uncertainties in global and regional temperature change using an ensemble of observational estimates-The HadCRUT4 data set: Journal of Geophysical Research, D, Atmospheres, v. 117, no. D8, p. 1-22, accessed December 26, 2019, at https://doi.org/10.1029/2011JD017187.

Moss, R.H., Edmonds, J.A., Hibbard, K.A., Manning, M.R., Rose, S.K., Van Vuuren, D.P., Carter, T.R., Emori, S., Kainuma, M., Kram, T., Meehl, G.A., Mitchell, J.F.B., Nakicenovic, N., Riahi, K., Smith, S.J., Stouffer, R.J., Thomson, A.M., Weyant, J.P., and Wilbanks, T.J., 2010, The next generation of scenarios for climate change research and assessment: Nature, v. 463, no. 7282, p. 747-756, accessed December 26, 2019, at https://doi.org/10.1038/nature08823.

Nakicenovic, N., and Swart, R., eds., 2000, Emissions scenarios-Intergovernmental Panel on Climate Change special report: Cambridge, United Kingdom, and New York, N.Y., Cambridge University Press, 599 p.

National Academies of Sciences, Engineering, and Medicine, 2016, Characterizing risk in climate change assessments-Proceedings of a workshop: Washington, D.C., The National Academies Press, 74 p. plus 2 appendixes.

National Research Council, 2010, Informing an effective response to climate change: Washington, D.C., The National Academies Press, 346 p.

O’Neill, B.C., Kriegler, E., Riahi, K., Ebi, K.L., Hallegatte, S., Carter, T.R., Mathur, R., and van Vuuren, D.P., 2014, A new scenario framework for climate change research-The concept of shared socioeconomic pathways: Climatic Change, v. 122, no. 3, p. 387-400, accessed December 26, 2019, at https://doi.org/10.1007/s10584-013-0905-2.

Program for Climate Model Diagnosis \& Intercomparison, [2019], CMIP coordinated experiments-Description: Program for Climate Model Diagnosis \& Intercomparison web page, accessed December 26, 2019, at https://pcmdi.llnl.gov/mips/cmip/coord_expt.html.

Randall, D.A., Wood, R.A., Bony, S., Colman, R., Fichefet, T., Fyfe, J., Kattsov, V., Pitman, A., Shukla, J., Srinivasan, J., Stouffer, R.J., Sumi, A., and Taylor, K.E., 2007, Climate models and their evaluation, chap. 8 of S. Solomon, D. Qin, M. Manning, Z. Chen, M. Marquis, K.B. Averyt, M. Tignor, and H.L. Miller, eds., Climate change 2007-The physical science basis. Contribution of Working Group I to the Fourth Assessment Report of the Intergovernmental Panel on Climate Change: Cambridge, United Kingdom, and New York, N.Y., Cambridge University Press, p. 591-662, accessed December 26, 2019, at https://www.ipcc.ch/site/assets/uploads/2018/02/ar4-wg1-chapter8-1.pdf.

Riahi, K., Rao, S., Krey, V., Cho, C., Chirkov, V., Fischer, G., Kindermann, G., Nakicenovic, N., and Rafaj, P., 2011, RCP 8.5-A scenario of comparatively high greenhouse gas emissions: Climatic Change, v. 109, no. 1, p. 33-57, accessed December 26, 2019, at https://doi.org/10.1007/s10584-011-0149-y.

Solomon, S., Plattner, G.-K., Knutti, R., and Friedlingstein, P., 2009, Irreversible climate change due to carbon dioxide emissions: Proceedings of the National Academy of Sciences, v. 106, no. 6, p. 1704-1709, accessed December 26, 2019, at https://doi.org/10.1073/pnas.0812721106. 
Stocker, T.F., Qin, D., Plattner, G.-K., Tignor, M., Allen, S.K., Boschung, J., Nauels, A., Xia, Y., Bex, V., and Midgley, P.M., eds., 2013, Climate change 2013-The physical science basis. Contribution of Working Group I to the Fifth Assessment Report of the Intergovernmental Panel on Climate Change: Cambridge, United Kingdom, and New York, N.Y., Cambridge University Press, 1,585 p., accessed December 26, 2019, at https://www.ipcc.ch/report/ar5/wg1/.

Taylor, K.E., Stouffer, R.J., and Meehl, G.A., 2012, An overview of CMIP5 and the experiment design: Bulletin of the American Meteorological Society, v. 93, no. 4, p. 485-498, accessed December 26, 2019, at https://doi.org/10.1175/BAMS-D-11-00094.1.

Thomson, A.M., Calvin, K.V., Smith, S.J., Kyle, G.P., Volke, A., Patel, P., Delgado-Arias, S., Bond-Lamberty, B., Wise, M.A., Clarke, L.E., and Edmonds, J.A., 2011, RCP4.5-A pathway for stabilization of radiative forcing by 2100: Climatic Change, v. 109, nos. 1-2, p. 77-94, accessed December 26, 2019, at https://doi.org/10.1007/s10584-011-0151-4.

U.S. Geological Survey Carbon Dioxide Storage Resources Assessment Team, 2013, National assessment of geologic carbon dioxide storage resources - Results (ver. 1.1, September 2013): U.S. Geological Survey Circular 1386, accessed December 26, 2019, at https://pubs.usgs.gov/circ/1386/. [Supersedes ver. 1.0 released June 26, 2013.] van Vuuren, D.P., Edmonds, J., Kainuma, M., Riahi, K., Thomson, A., Hibbard, K., Hurtt, G.C., Kram, T., Krey, V., Lamarque, J.-F., Masui, T., Meinshausen, M., Nakicenovic, N., Smith, S.J., and Rose, S.K., 2011, The representative concentration pathways-An overview: Climatic Change, v. 109, no. 1, p. 5-31, accessed December 26, 2019, at https://doi.org/10.1007/s10584-011-0148-z.

van Vuuren, D.P., Stehfest, E., den Elzen, M.G.J., Kram, T., van Vliet, J., Deetman, S., Isaac, M., Klein Goldewijk, K., Hof, A., Mendoza Beltran, A., Oostenrijk, R., and van Ruijven, B., 2011, RCP2.6-Exploring the possibility to keep global mean temperature increase below $2^{\circ} \mathrm{C}$ : Climatic Change, v. 109, no. 1, p. 95-116, accessed December 26, 2019, at https://doi.org/10.1007/s10584-011-0152-3.

World Climate Research Programme, 2019, WCRP Coupled Model Intercomparison Project (CMIP): World Climate Research Programme, accessed October 9, 2019, at https:/www.wcrpclimate.org/wgcm-cmip.

Wuebbles, D.J., Fahey, D.W., Hibbard, K.A., Dokken, D.J., Stewart, B.C., and Maycock, T.K., eds., 2017, Climate science special report—Fourth national climate assessment, volume I: Washington, D.C., U.S. Global Change Research Program, 470 p., accessed December 26, 2019, at https://doi.org/10.7930/J0J964J6.

Zhu, Z., and Reed, B.C., eds., 2014, Baseline and projected future carbon storage and greenhouse-gas fluxes in ecosystems of the eastern United States: U.S. Geological Survey Professional Paper 1804, 204 p., accessed December 26, 2019, at https://doi.org/10.3133/pp1804. 
Manuscript approved for publication on May 19, 2020

For further information on USGS climate impacts and adaptation science, visit the Climate Adaptation Science Centers website at https://www.usgs.gov/land-resources/ climate-adaptation-science-centers.

Publishing support provided by the U.S. Geological Survey Science Publishing Network, Reston Publishing Service Center

Cathy Y. Knutson, layout 